\title{
An Analysis of the Aspects Hampering Informal Sector Tax Administration: Case of the Zimbabwe Revenue Authority
}

\author{
Adegbola Otekunrin ${ }^{1}$, Kudzanai Matowanyika ${ }^{2} \&$ Chena Tafadzwa $^{2}$ \\ ${ }^{1}$ Department of Accounting \& Finance, Landmark University, Nigeria \\ ${ }^{2}$ Graduate Business School, Chinhoyi University of Technology, Chinhoyi, Zimbabwe \\ Correspondence: Adegbola Otekunrin, Department of Accounting \& Finance, Landmark University, Nigeria.
}

Received: September 27, 2020

Accepted: November 4, 2020

Online Published: June 22, 2021

doi:10.5430/ijfr.v12n5p10

URL: https://doi.org/10.5430/ijfr.v12n5p10

\begin{abstract}
The main focus of the study was to ascertain the potential of the informal sector to provide much-needed revenue for the government. It also focused on the challenges faced in informal sector revenue taxation and possible solutions thereof. The Zimbabwe revenue authority has maintained presumptive tax for the sector and subcontracting to the city of Harare for the collection of revenue from the informal sector. Despite all this, the industry still underperformed in terms of revenue raised. The study sought to find out challenges of taxing the informal sector, the potential of the informal sector, the effectiveness of the Zimbabwe revenue authority in taxing the informal sector, and possible ways of improving the taxing of this rampant sector. The study found out that there is great potential from the informal sector, but turning it into tangible gains has been elusive due to political interference, lack of proper infrastructure, unfair application of tax laws and general mistrust of the government. The study recommended that the government ought to play an active role by making sure there is the political will to make sure that players in the informal sector contribute to the focus in line with Adam Smith's general principles which include fairness and equity. There is a need for staffing levels to be commensurate with the workloads and also the motivation of the employees. The research also recommended the adaptation of Information Communication Technology to ensure accountability and traceability of transactions in the informal sector as they move away from a cash-based system recommendation.
\end{abstract}

Keywords: informal sector, presumptive tax, tax administration, revenue

\section{Introduction}

Income from taxes supports the essential services of governments, and the need to raise revenue domestically always generated much interest virtually in every country (Munjeyi, 2017). The challenges for the African economies are that income from broad-based taxation is below the minimum global rate of $15 \%$ of GDP (Mascagni, Moore \& McCluskey, 2014). This leads to focus on the rampant informal sector in Africa which is taking up a significant portion of GDP but has seemingly failed to fill the gap in terms of revenue contribution through taxation Dube (2014). Most of the players in the informal sector are not contributing much to revenue from taxation (Sikwila, Kareza \& Mungadza, 2016). The informal sector has become a consistent phenomenon for both the developed and developing countries with greater prevalence in the least developed countries (Besley \& Torsten, 2014).

Despite the size of the informal sector in Africa and Zimbabwe, in particular, the industry remains the least taxed. Zimra introduced the presumptive tax in 2005, yet it is still facing challenges in tapping into the industry. Zimbabwe, despite having the large informal sector, has little to show in terms of revenue from the industry (ZIMRA, 2019). Zimbabwe's informal sector accounts for a significant share of the economy and has been under the spotlight since the introduction of the presumptive tax in 2005. Despite having been brought into the tax net for over a decade, the tax head has consistently underperformed in relation to other tax heads (Zivanai, Onias, Nhamo, Lloyd \& Michael, 2014). The presumptive tax being used by ZIMRA does not offer an opportunity for the businesses to formalise fully, so the firms continue to evade tax (Zivanai, Onias, Nhamo, Lloyd \& Michael, 2014). The meager contribution of the informal sector to taxation calls for research as to the challenges being faced by Zimbabwe in this area.

There is a shortage of information as to challenges faced by tax authorities, and the ZIMRA in particular in taxing the informal sector. Developing countries face problems when collecting taxes from the informal ever-increasing 
industry. More often than not, there is a gap between what is collected and what is expected, this was enunciated by (Munjeyi, 2017). According to Dube (2014), there is a significant knowledge gap in how taxes informal sector taxation is administered in developing countries. It for these reasons, this study explored the potential of the informal sector to provide the revenue with the government needs and examined ZIMRA's effectiveness in taxing the informal sector. This study also identifies the challenges faced by Zimra in informal sector revenue collection and explores possible ways to increase informal sector revenue collection.

\subsection{Research Propositions}

H1: Challenges faced in informal sector taxation significantly affect the revenue collected

$\mathrm{H} 2$ : Challenges faced in informal sector taxation have little bearing on the revenue realised

\section{Literature Review}

\subsection{Defining the Informal Sector}

The informal sector has been given various definitions in the literature, ranging from informal, hidden, black, underground, grey, clandestine, illegal, unreported, non-cash, and parallel (Fleming, Roman\& Farrell, 2000). The informal sector is defined by Kenyon (2007) as those types of businesses that are not subject to government laws and regulation, including taxation. Joshi, Prichard and Heady (2014) define the informal sector as companies that are not registered and are not complying with rules and regulations. The definition dwells on the legal status of the firm, and it's the one that's going to be used for the study.

\subsection{Presumptive Tax}

Presumptive tax is a tax that is based upon some presumed and verified indicators, for an example, seating capacity of a bus. Presumptive tax is an indirect form of taxation where tax liability is based on presumed income (ZIMRA, Zimra Website, 2019). Presumptive taxes are generally favoured because they have administrative simplicity and economic efficiency. They offer simplicity as informal sector operators are not required to keep detailed records like the formal sector. Presumptive taxes are also expected to combat tax avoidance, which is possible when the presumed indicators of tax liability are difficult to hide. If the indicators for tax assessment are objective, presumptive tax is expected to offer a more equitable distribution of the tax burden. The collection of presumptive tax can be outsourced to other departments, which are closer to the taxpayer, thus reducing administrative costs and providing convenience to clients. According to Munjeyi (2017), informal sector tax administration in Zimbabwe faces several challenges from lack of competent staff, politics, the attitude of officers and conflict of interest where some of the officers also carry out activities in the informal sector. The major challenge of informal sector taxation is that most of the firms do not register for tax purposes (Dube, 2014). Wellalage \& Stuart Locke (2016) singles out the lack of registration for tax purposes by the informal businesses as one of the most significant challenges in tax administration.

\subsection{Tax Administration}

Tax administration is generally the responsibility of the central government, and in Zimbabwe, the function is given to Zimra. The primary purpose is to collect the revenue due to the state at the least possible cost. Tax administrators perform a wide range of activities with the registration of taxpayers, detection of non-registration and false registration, processing of tax returns, withholdings and third-party information, verification or examination of the correctness and completeness of received information to audit activities being the common ones (Uganda Revenue Authority, 2011). Katairo (2011) posits that a fair tax should be one which is easy to understand as to the on the amount of taxes that should be paid and when it is due. The ways taxes are collected determine the number of taxpayers who do comply (Katairo, 2011). The yield, incidence, and efficiency of a tax system are affected by how it is administered (Bird, 2015). For countries to increase revenue collection there is a need for an effective Tax administration which is capable of identifying new taxpayers and bringing them into the tax net and also develop new collection techniques. There is a need to avoid tax imposition, which in turn result in tax evasion and lower than anticipated revenue.

\subsection{Theories of Taxation}

\subsubsection{Deterrent Theory}

According to Williams and Schneider (2013), the deterrence approach is based on the fact that the citizens are viewed as rational actors who engage in activity after weighing whether the benefits their actions outweigh the penalties. This was termed the classic utilitarian theory of crime, where people engage in crime when the benefits outweigh the expected penalty and probability of being caught. The concept viewed people who do not pay taxes as 
rational actors who engage in tax evasion because the benefits are more significant than the expected costs of being caught and punished. It was therefore argued that the penalties and potential for detection should outweigh the potential for tax evasion. This deterrence approach was subsequently widely adopted as an approach for explaining and tackling the informal sector (Williams \& Schneider, 2013). The kind of approach may not be conducive for countries like Zimbabwe where engaging in the informal sector is not much of choice but a call of nature and circumstances where there are no formal jobs for a larger proportion of citizens to engage in. The motive of taxation for Zimra is to raise revenue, which augurs well with a situation where the tax authority would rather see the informal sector being the backbone or the mainstay of revenue due to its great share of GDP.

\subsubsection{Tax Morale Approach}

The tax morale approach focuses on the morale of the economic actors as opposed to the rationality concept as emphasised by the deterrent approach. It has been realised that some people comply with tax obligations voluntarily even when the level of penalties and risks of detection suggests that they should not if they were genuinely rational economic actors (Alm \& Torgler, 2011). The tax morale approach grew from the attention of the tax contract between the state and its citizens (Alm \& Torgler, 2011). The contract between the state and its citizen's borders on the fact that the state collects money from its citizens and in turn provides services to the citizens. The major problem in developing countries is low morale and lack of trust. A significant cause of low morale and lack of trust is the rampant corruption levels where even those who ordinarily would have wanted to pay taxes to end up not paying because their governments hardly provide sufficient beneficial services to the citizens and Zimbabwe is not an exception. Citizens, most especially in the informal sector, struggled always to provide themselves with essential services to survive. The taxpayers generally view the government as taking only from them without contributing anything to their success. (Levi, 1998)

\subsubsection{Slippery Slope Approach}

In between the deterrent and tax morale approach lies what is known as the slippery slope approach. The primary focus of the slippery slope is to deal with the ever-persistent aspect of tax evasion (Frey \& Torgler, 2007). The approach could be an option where the objective would be to raise revenue but at the same time ensuring good relations with the taxpayer. This can be seen as the carrot and stick approach where non-payers are sanctioned, and those with high tax morale are appreciated. This is, however, mainly done on visible taxpayers (ZIMRA, 2019). Since the informal sector is sometimes called the shadow economy visibility is difficult, hence identifying performers and none performers is a job in itself. This is different from the formal sector where companies try to outdo each other $r$ in revenue contribution (Sakuhuni, 2014)

\subsubsection{Religionist Theory}

The religionist theory is more recent and has not found many tracts in taxation circles. This is due to the difficulties in measuring the contributions and effect of religion on tax behaviour. Religious matters are very subjective, and generally depend on who is telling the story. What is right in one religion may not be in another (Ariel, 2012). African societies generally suffer from a proliferation of foreign religions which may not be grounded to the core of the society. People may end up paying lip services saying one thing and doing the other, Economic hardships political upheavals and broken promises all play a part in undermining peoples resolve to build their nations through paying taxes. This creates severe challenges for tax administrators as they try to raise revenue for the government.

\subsection{General Limitations of Informal Sector Taxationin Developing Countries}

The significant challenges hindering effective taxation of the informal sector can be grouped into three categories: accountability factors; organizational and resource constraint factors, and political considerations. There are various challenges with regards to accountability for all the transactions that occur in the informal sector. Informal sector players generally transact in cash with the absence of record-keeping that makes it possible for the informal operators to conceal their income and evade effective taxation (Mwanza, 2015). Taxing the informal sector is considered labour intensive and therefore hard to tax and administer. The major challenge is the lack of funds to administer the informal sector taxation. Most of the officers are not highly motivated due to poor working conditions (Mwanza, 2015). Effective informal sector taxation is also hindered by political interference (Joseph, 2015). Most African governments take advantage of the numbers in the informal sector to win votes by their control on the sector. This emanates from the fact that players in the informal sector have a potentially sizeable political voice even though they do not contribute much to the economy. According to Dalu, Maposa, Dalu and Pabwaungana (2013), the politicians always promise not to collect taxes for the players in the sector and keep the police as well as inspectors from harassing you. 


\subsection{Empirical Review}

In Pakistan, the presumptive tax code was studied by Memon (2013). Self-employed professionals and employees under presumptive tax systems were compared in term of tax burdens, and the result shows that people that earn a smaller amount of income pay more taxes than people that earn more. This result is against the principle of equity and fairness and low tax morale for both the formal and informal sector. Brou and Collins (2001) studied an instrument to raise government revenues and as well as domineering informal sector growth. The result shows that direct taxation is a better instrument to raise government revenues is concerned with controlling the growth of the informal sector. In a study of selected African countries using presumptive tax regimes, Mwanza (2015) concluded that equity and fairness that can raise tax morale is achievable by use presumptive taxes in particular among selfemployed (who evade tax effortlessly) and formal sector salaried employees ( who unable to evade tax due to withholding schemes). However, Data in developing countries is very sparse, leading difficulties in measuring administrative effectiveness (Dube, 2014). On a seemingly, opposite note, Munjeyi (2017) states that Zimbabwe's tax legislation has been seen as not adequately covering the informal sector, thus placing the tax burden on the few companies which are still functional. This will have a detrimental impact on the taxpayer's willingness to comply voluntarily (Feige, 2016). According to AFRODAD (2014), Zimbabwe has not made much progress in taxing the informal sector. Joshi, Prichard \& Heady (2014) also concurs by saying that there is little known about the government's commitment to informal sector tax reform.

\section{Methodology}

The research used a case study design to get to the depth of the challenges being experienced by the ZIMRA. The researcher was able to ask questions as to why the informal sector is not performing as expected in terms of revenue generation, and what are the challenges of informal sector tax administration in ZIMRA? The research used the embedded case study approach in line with Saunders, Lewis and Thornhill (2009). The research used the mixed method of study (both qualitative and quantitative approaches). The target population was 105 officers who work in the audit department of the ZIMRA. The sample size for the study was thirty-eight respondents' tax officials out of the hundred and five. Usually, the minimum and acceptable sample size for a quantitative research design would be $30 \%$ of the population (Scandura \& Williams, 2013; Otekunrin, Fagboro, Nwanji, Asamu, Ajiboye \& Falaye, 2019; Otekunrin, Asamu, Oye \& Olowookere, 2019; Otekunrin, Nwanji, Agba, Olowookere, Fakile, Lawal, Ajayi \& Falaye, 2018). When using non-probability sampling which is more suitable for case study research design, there are no clear rules of selecting the sample size (Munyoro, Chikombingo \& Nyandoro, 2016; Otekunrin, Iyoha, Uwuigbe \& Uwuigbe, 2017; Otekunrin, Nwanji, Egbide, Fakile, Lawal, Ajayi, Falaye \& Eluyela, 2018). When faced with such a scenario of a heterogeneous population (Creswell, 2007) suggests that a sample of between twenty-five and thirty can be sufficient. The research used structured questionnaires as the research instrument to gather primary data. The researcher collected primary data through the use of questionnaires and used annual reports, publications from the United Nations, monthly reports, ZIMRA revenue performance reports, and research journals for secondary data. A total of one thirty-eight (100\%) questionnaires were issued, and a total of thirty-four $(89 \%)$ were completed and returned. The response rate of $89 \%$ is high enough in making conclusions and recommendations according to Baruch (1999) who suggested that for most academic studies involving top management or organisations' representatives a response rate of approximately $35 \%$ is reasonable.

Table 1. Population, sample size and questionnaires returned

\begin{tabular}{llllll}
\hline Position & Population & Sample & Sample Size & $\begin{array}{l}\text { Questionnairess } \\
\text { ent }\end{array}$ & $\begin{array}{l}\text { Questionnaires } \\
\text { returned }\end{array}$ \\
\hline managerial & 6 & 3 & $50 \%$ & 3 & 2 \\
\hline supervisory & 20 & 9 & $45 \%$ & 9 & 8 \\
\hline Revenue officers & 79 & 26 & $33 \%$ & 26 & 24 \\
\hline TOTAL & 105 & 38 & $36 \%$ & 38 & 34 \\
\hline
\end{tabular}

Source: Researcher (2018) 


\section{Results}

Role of the informal sector

Table 2. The role of the informal sector

\begin{tabular}{lll}
\hline & Mean & Sta. Dev \\
\hline Contribution to the national output & 3.1216 & 0.48863 \\
\hline Job creation and income distribution & 2.1847 & 0.41743 \\
\hline Skills acquisition in training & 2.8765 & 0.34567 \\
\hline Increasing the pace of innovation acquisition & 3.5543 & 0.58678 \\
\hline
\end{tabular}

Source: Researcher (2018)

The results in Table 2 show that the informal sector plays a vital role in contributing to the national output with a mean score of 3.1216 and a standard deviation of .48863 . The results also show that the informal sector contributes massively to job creation and income distribution with a mean score of 2.1847 and a standard deviation of 0.41743 , and this correspond with Schneider and Buehn (2009). The study results indicate that the informal sector plays a role of increasing the pace of innovation acquisition with a mean score of 3.5543 and a standard deviation of 0.58678 and it corresponds with Araujo-Bonjean and Chambas (2005).

\subsection{Why Tax the Informal Sector}

Table 3. Motivation for taxing the informal sector

\begin{tabular}{llllll}
\hline \multirow{2}{*}{ Valid } & To raise revenue & 15 & 44.1 & 44.1 & 44.1 \\
\cline { 2 - 6 } & To improve GDP & 15 & 44.1 & 44.1 & 88.2 \\
\cline { 2 - 6 } & Improving administrative effectiveness & 4 & 11.8 & 11.7 & 100 \\
\cline { 2 - 6 } & Total & 34 & 100 & 100 & \\
\hline
\end{tabular}

Source: Researcher (2018)

The results on Table 3 show that the main reasons for taxing the informal sector is to raise revenue for the government and to improve the country's GDP (both the variables had a $44.1 \%$ respectively) and this is similar to Masarirambi (2013), Munjeyi (2018) as well as Mbaye and Benjamin (2014). This indicates that the informal sector is contributing much to the growth of Gross Domestic Product as is the case of Malaysia according to Gupta and Tareq (2008). The study further discovered another motivation in improving administrative effectiveness where the revenue from the informal sector can be used to improve the effectiveness of the authority.

4.2 Reasons Why the Informal Sector Is Hard to Tax

Table 4. Reasons why the informal sector is hard to tax

\begin{tabular}{llll}
\hline Response & Distribution & & \\
\cline { 2 - 4 } & Frequency & Percent & Cumulative Percent \\
\hline Peripatetic informal sector business & 10 & 29.4 & 29.4 \\
The predominance of cash transactions & 15 & 44.1 & 73.5 \\
Poor record-keeping practices & 5 & 14.7 & 88.2 \\
High illiteracy rate & 4 & 11.8 & 100 \\
Total & 34 & 100 & \\
\hline
\end{tabular}

Source: Researcher (2018) 
The study outcomes on Table 4 show that $29.4 \%$ of the respondents were of the view that informal sector entrepreneurs do not have a permanent place of business; hence making locating them for tax difficult for tax authorities. The result corresponds to Ayee (2007). $44.1 \%$ of the respondents agreed that the predominance of cash transactions also makes it is extremely difficult for revenue authorities to figure how much the businesses are making and this is worsened by poor record-keeping practices which $14 \%$. The result corresponds with Joshi, Prichard \& Heady (2014).

\subsection{Challenges of Informal Sector Taxation}

Table 5. Challenges faced in taxing the informal sector

\begin{tabular}{llllll}
\hline & Frequency & Percent & Valid Percent & Cumulative Percent \\
\hline Valid & Emergence of illegal agents & 12 & 35.3 & 35.3 & 35.3 \\
\cline { 2 - 5 } Lack of proper physical structures & 8 & 23.5 & 23.5 & 58.8 \\
\cline { 2 - 5 } Administrative Challenges & 5 & 14.7 & 14.7 & 73.5 \\
\cline { 2 - 5 } Politics & 9 & 26.5 & 26.5 & 100 \\
\cline { 2 - 5 } Total & 34 & 100 & 100 & \\
\hline
\end{tabular}

Source: Researcher (2018)

The results on Table 5 show that emergence of illegal agents, lack of proper physical structures, administrative challenges and politics are the major challenges being faced by ZIMRA in taxing the informal sector with corresponding percentages of $35.3 \%, 23.5 \%, 14.7 \%$ and $26.5 \%$ of the respondents agreeing on these facts. The results are similar to that of Dube (2014), Utaumire, Mashiri, \& Mazhindu (2013) as well as Masarirambi (2013).

\subsection{Reasons Why People Evade Informal Sector Taxation}

Table 6. Reasons for tax evasion by the informal sector

\begin{tabular}{llll}
\hline Response & Distribution & \\
\cline { 2 - 4 } & Frequency & Percent & Cumulative Percent \\
\hline Too high tax rates & 11 & 32.3 & 32.3 \\
knowing others are not paying & 14 & 41.2 & 73.5 \\
Unfair application of tax laws & 4 & 11.8 & 85.3 \\
Mistrust of the Government & 5 & 14.7 & 100 \\
Total & 34 & 100 & \\
\hline
\end{tabular}

Source: Researcher (2018)

Based on Table 6 result, the respondents agreed that most informal sectors evade tax because of various reasons. These include too high tax rates $(32.3 \%)$, knowing others are not paying $(41.2 \%)$, unfair application of tax laws $(11.8 \%)$ and mistrust of the Government (14.7\%), i.e. government misuse the tax money. The officials use such money for their gain, not the benefit of the country (Mwila, Manley, Chileshe, Phiri \& Mpembamoto, 2011). 


\subsection{Taxing the Informal Sector}

Table 7. Tax from informal sector since 2005 (Millions)

\begin{tabular}{lllllll}
\hline & 2005 & 2007 & 2009 & 2012 & 2015 & 2018 \\
\hline Turnover tax & 4.5 & 9.87 & 13.11 & 18.75 & 23.12 & 24.1 \\
\hline Base tax & - & 0.07 & 0.09 & 0.04 & 0.03 & 0.03 \\
\hline Advance income tax & - & - & - & 12.3 & 60.8 & 64.6 \\
\hline Presumptive tax is on commuters & 1 & 1.05 & 1.76 & 1.82 & 2.29 & 2.15 \\
\hline Total informal sector tax & 5.5 & 10.98 & 14.96 & 32.9 & 86.2 & 90.87 \\
\hline Total formal sector tax & 2038 & 2463 & 2964 & 3841 & 4699 & 5073 \\
\hline Informal sector tax (\%of income tax) & 0.27 & 0.45 & 0.50 & 0.86 & 1.84 & 1.79 \\
\hline
\end{tabular}

Source: Researcher (2018)

The results from the data collected at ZIMRA shows that taxing the informal sector has been sluggish since the introduction of a tax for the informal sector in 2005. Table 7 shows slow growth from 2005 to 2018. From 2005-2007, tax turnover from informal sector grew from 4.5 million to 9.87 million. This shows growth of 5.37 million in 2years. From 2012-2018, tax turnover from informal sector grew from 18.75 million to 24.1 million. This shows growth of 5.36 millionin 6 years. The slow grow this due to the administrative challenges that ZIMRA and this is similar to Dube (2014) result.

\subsection{Ways of Improving Informal Sector Tax Administration}

Table 8. Ways to improve informal sector tax administration

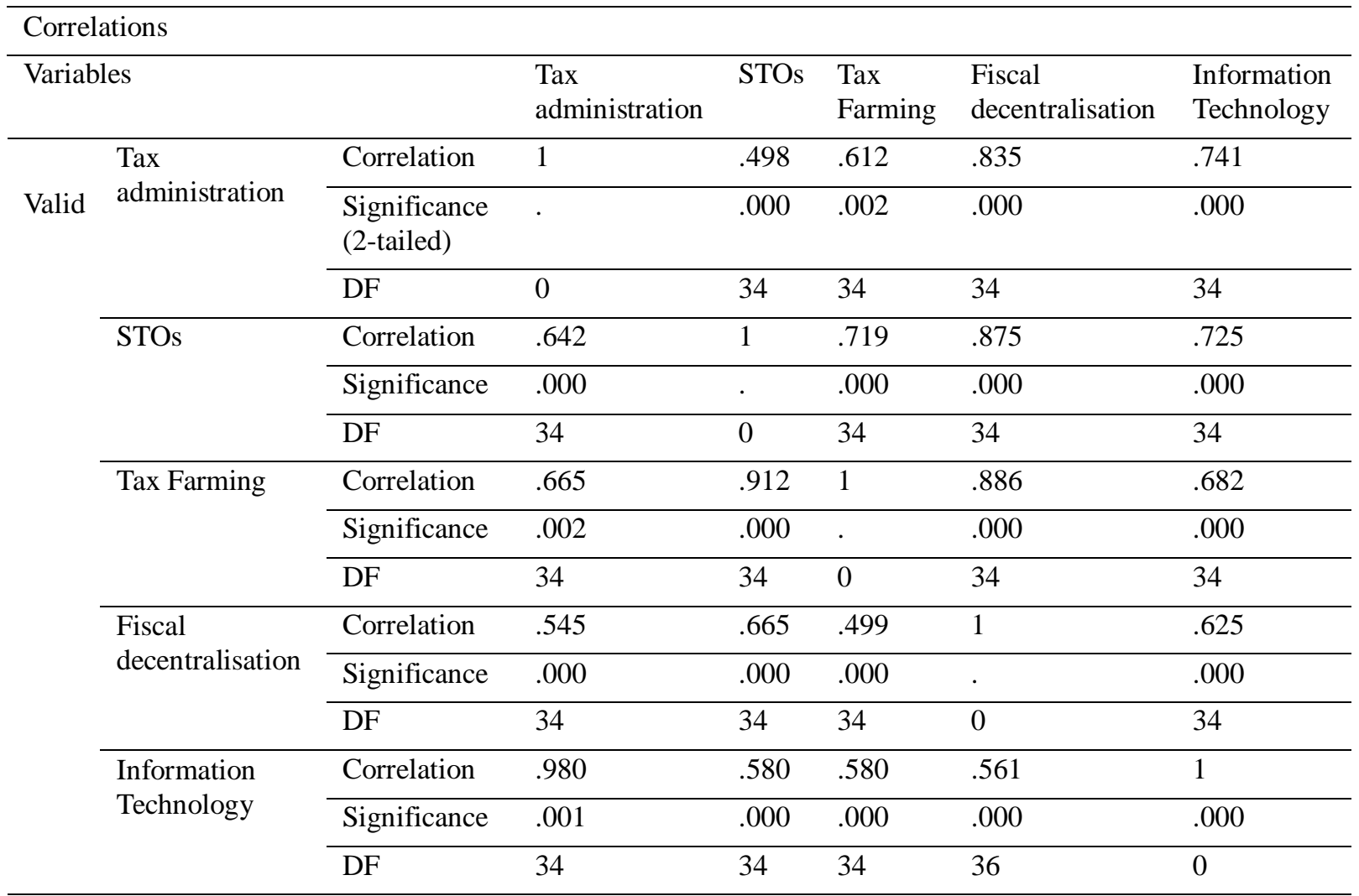

Source: Researcher (2018) 
Table 8, the correlation matrix shows the ways to improve informal tax administration. The Pearson Product Correlation Coefficient shows a significant partial correlation between tax administration and STOs ( $r=0.798$, $\mathrm{P}<0.05$ ). This implies that an STO is a major way of improving the informal sector tax administration. However, a partial relationship also suggests that STO may not have a significant effect on administrative efficiency on its own. Tax authorities like ZIMRA, for instance, have no sufficient the workforce as well as other resources enforce compliance and successfully monitor the informal sector. The Pearson Product Correlation Coefficient shows a significantly strong correlation between tax farming as well as fiscal decentralisation and tax administration; with tax farming $(r=0.612, \mathrm{P}<0.05)$ and fiscal decentralisation $(\mathrm{r}=0.835, \mathrm{P}<0.02)$. The result implies that tax farming and fiscal decentralisation plays a role in freeing tax authorities to focus on monitoring and selective audits. The study revealed that the effectiveness of tax farming is dependent on the capacity of the agents tasked with the collection and their ability to eliminate corruption. Pimhidzai \& Fox (2012) in their study, found out that tax farming which involves the use of agents and intermediaries is an effective way to collect tax from the informal sector. Their research concluded that revenue authorities must embrace the use of agents as they are an effective way of gathering tax from the informal sector. The study shows a very strong correlation between information technology and tax administration $(\mathrm{r}=0.980, \mathrm{P}<0.02)$, implying that information technology is a way of improving informal sector tax administration. The result is the same with Gurtoo and Williams (2009) who studied the role of technology in revenue collection in India. Their research found out that the use of technology such as blockchain provides serious monitoring too by revenue authorities. As a result, results in more revenue being collected as the systems reduce the cases of evasion.

\subsection{Descriptive Statistics}

The regression analysis

The regression analysis models were done to explain the ways of improving informal tax administration, taking into consideration four variables (STOs, Tax Farming / TF, Fiscal Decentralisation / FD and Information Technology / IT).

Table 9. Regression model 1

\begin{tabular}{|c|c|c|c|c|c|c|c|c|c|c|c|c|}
\hline \multicolumn{13}{|c|}{ Unstandardized Standardized } \\
\hline \multicolumn{2}{|c|}{ Coefficients } & \multicolumn{2}{|c|}{ Coefficients } & \multicolumn{4}{|c|}{.95 Confi. Interval for B } & \multicolumn{5}{|c|}{ Correlations } \\
\hline & B & Std.E & Beta & $\mathrm{t}$ & sig & lowerB & upperB & $\begin{array}{l}\text { Zero- } \\
\text { Order }\end{array}$ & Partial & Part. & Tolerance & W \\
\hline STOs & 9.075 & $3 \mathrm{MB}$ & & 2.946 & 0.008 & 1518 & $1.556 \mathrm{E} 10$ & & & & & \\
\hline $\mathrm{TF}$ & $1.313 \mathrm{E} 9$ & 3.682 & 0.595 & 3566 & 0.002 & $5.364 \mathrm{E} 8$ & $2.090 \mathrm{E} 9$ & 0.753 & 0.658 & 0.532 & 0.798 & 1.251 \\
\hline FD & $3.682 \mathrm{E} 8$ & 1.217 & -0.19 & -1.22 & 0.239 & $-4.1 \mathrm{E} 8$ & $1.092 \mathrm{E} 8$ & -4.42 & -0.282 & -0.18 & 0.887 & 1.251 \\
\hline IT & 11.834 & 8482 & 0.221 & 1.394 & 0.180 & -6.062 & 29.732 & 0.452 & 0.320 & 0.207 & 0.881 & 1.132 \\
\hline
\end{tabular}

Source: Researcher (2018)

Note: Security Token Offerings-STOs; Tax Farming-TF; Fiscal Decentralisation-FD and Information Technology-IT. (Dependent variable $=$ Tax Administration (Challenges), Std.E-standard error, lower B= lower Bound, upper B = upper Bound)

From the regression Table 9, tolerance which is the indicator of how much of the variability of a specified independent variable is not explained by the other independent variables are given and also given is the Variance Factor (VF). Suppose the Tolerance value is less than 0.1. In that case, it explains that the multiple correlations with the other variables in the study are very high and this suggests a possibility of multicollinearity. Also, if the VF values are more than 10, it indicates multicollinearity. From the table, no tolerance value is less than 0.1 and the values of VF are not more than 10, and this depicts that the multicollinearity assumption was not violated. The table shows a summary of the model 1 regression. 
Table 10. Summary of regression model 2

\begin{tabular}{llllllllll}
\hline Model & $\mathrm{R}$ & $\begin{array}{l}\mathrm{R} \\
\text { Square }\end{array}$ & $\begin{array}{l}\text { Adjusted } \\
\text { Square }\end{array}$ & $\begin{array}{l}\text { Standard error } \\
\text { of the estimate }\end{array}$ & $\begin{array}{l}\mathrm{R} \text { Square } \\
\text { change }\end{array}$ & F Change & Df1 & Df2 & $\begin{array}{l}\text { Sig.F } \\
\text { change }\end{array}$ \\
\hline 1 & $.786^{\mathrm{a}}$ & .778 & .552 & $5.557 \mathrm{E} 9$ & .622 & 9.927 & 3 & 16 & .001 \\
\hline
\end{tabular}

Source: Researcher (2018)

From the model 1 summary, TF and IT substantially correlate with Tax Administration challenges (TAC). Thus, a unit change in any one of those two variables will reduce the challenges faced by the tax administration in taxing the informal sector. Adjusted R-square measures that the variance proportion on Tax administration which was the dependent variable that was depicted by variations on the independent variables. R-square adjusted indicated that $55.2 \%$ of the variance is explained in the model 1 summary. Thus, the adjusted R-square depicts that the variation in Tax administration changes with change in STOs, Tax Farming, Fiscal Decentralisation and Information Technology. Tax farming (use of agents and middlemen) was found to have the largest Beta, and this means that it has the strongest contribution to explaining Tax administration challenges when the variance explained by other variables is controlled for. STOs made less contribution in explaining tax administration challenges, and the other two variables have a significant value greater than 0.05 , which explains the variables make a unique contribution to the equation. The equation explains that the adoption and or use of the variables STOs, Fiscal Decentralisation, Tax Farming and Information Technology would eventually lead to a decrease in the challenges of informal sector tax administration. The results from the equation tallies with those of Baunsgaard (2005) who studied ways of curbing the challenges of informal sector tax administration in Vietnam and found out that the use of STOs, new technology systems and fiscal decentralisation plays a vital positive role in eliminating the challenges tax administrations face in taxing the informal sector.

Table 11. Regression model 3

\begin{tabular}{|c|c|c|c|c|c|c|c|c|c|}
\hline & \multicolumn{2}{|c|}{$\begin{array}{l}\text { Unstandardized } \\
\text { coefficients }\end{array}$} & \multicolumn{3}{|c|}{$\begin{array}{l}\text { Standardized } \\
\text { coefficients }\end{array}$} & \multirow{2}{*}{$\begin{array}{l}\text { Correlations } \\
\text { Zero Order }\end{array}$} & \multirow{2}{*}{$\begin{array}{l}\text { Correlations } \\
\text { Partial }\end{array}$} & \multicolumn{2}{|c|}{$\begin{array}{l}\text { Collinearity } \\
\text { Statistics }\end{array}$} \\
\hline & B & $\begin{array}{l}\text { Standard } \\
\text { Error }\end{array}$ & Beta & $\mathrm{t}$ & sig & & & Tolerance & VF \\
\hline Constant & $1.07 \mathrm{E}+10$ & $2.71 \mathrm{E} 09$ & & 3.98 & .001 & & & & \\
\hline STO & $-2.68 \mathrm{E} 08$ & $1.15 \mathrm{E}+08$ & -0.340 & -3.3 & .033 & -0.430 & -0.48 & 0.97 & 1.020 \\
\hline $\mathrm{TF}$ & 6.634 & 7.890 & 0.120 & 0.73 & .468 & 0.450 & 0.176 & 0.78 & 1.286 \\
\hline TI & $3.34 \mathrm{E}+08$ & $9.05 \mathrm{E}+07$ & 0.603 & 3.62 & .002 & 0.590 & 0.65 & 0.78 & 1.278 \\
\hline $\mathrm{R}$-square & 725 & & & & Adj & ted R-squar & 658 & & \\
\hline
\end{tabular}

Source: Researcher (2018)

Note: Security Token Offerings-STOs; Tax Farming-TF; Fiscal Decentralisation-FD and Information Technology-IT

From Table 11 above, the adjusted R-square show that 65.8 of the variance depicted and explained in Tax administration challenges changes with change in STOs, Fiscal Decentralisation, Tax Farming and Information Technology. Information technology has the largest beta depicting that it makes a unique strongest contribution to explaining challenges in informal sector tax administration if the other variables are held constant. The model of regression indicates that an increase in the use of technology and tax farming leads to a decrease in the challenges in tax administration. Still, a change in Security Token Offerings or the adoption of it may not significantly reduce the challenge in informal sector tax administration. The results are in tandem with Glenday (2006) who found out those STOs leads towards fiscally feasible and efficient liberalization in informal sector taxation. 
Table 12. Regression model 4

\begin{tabular}{|c|c|c|c|c|c|c|c|c|c|c|c|c|}
\hline \multirow{2}{*}{$\begin{array}{l}\text { Unstandardized } \\
\text { Coefficients } \\
\end{array}$} & & \multicolumn{11}{|l|}{ Standardized } \\
\hline & & coefficients & & .95 Confidenceintrval for $B$ & & Correlations & & & & & & \\
\hline & B & St.E & Beta & $t$ & Sig & lowerB & upperB & Zero-order & partial & Part. & Tolerance & $f$ \\
\hline Constant & 8.904E9 & 2.984E8 & & & 2.981 & .008 & $2.574 \mathrm{E} 9$ & $1.530 \mathrm{E} 10$ & & & & \\
\hline STO & -1.9979 & $1.232 \mathrm{E} 8$ & -0.257 & -1.610 & 0.125 & $-4.621 \mathrm{E} 8$ & $6.245 \mathrm{E} 7$ & -0.130 & -0.374 & -0.230 & 0.818 & 1.22 \\
\hline TF & 7.3830 & 0.870 & 0.137 & 0.811 & 0.112 & -11.207 & 25.976 & 0.130 & 0.240 & 0.120 & 0.760 & 1.28 \\
\hline FD & 1.9208 & 1.323E8 & 0.335 & 1.152 & 0.165 & $-8.872 \mathrm{E} 7$ & $1.876 \mathrm{E} 8$ & 0.690 & 0.350 & 0.210 & 0.359 & 2.86 \\
\hline IT & 7.348E8 & $5.346 \mathrm{E} 8$ & 0.332 & 1.370 & 0.187 & $-3.630 \mathrm{E} 9$ & $1.730 \mathrm{E} 9$ & 0.730 & 0.420 & 0.190 & 0.350 & 2.83 \\
\hline
\end{tabular}

Source: Researcher (2018)

Note: Security Token Offerings-STOs; Tax Farming-TF; Fiscal Decentralisation-FD and Information Technology-IT

Regression model 3 indicates tolerance and VF values. The table shows that tolerance values exceed 0.1 and also the VF values are less than 10. This depicts that the study neither does nor desecrated the assumption of multicollinearity. The results depict that Tax Farming, Fiscal Decentralisation and Information Technology correlate substantially with Tax Administration Challenges.

Table 13. Summary of regression model 4 (the tolerance and VF values)

\begin{tabular}{llllllllll}
\hline Model & $\mathrm{R}$ & $\begin{array}{l}\mathrm{R} \\
\text { Square }\end{array}$ & $\begin{array}{l}\text { Adjusted } \\
\text { Square }\end{array}$ & $\begin{array}{l}\text { Standard error of } \\
\text { the estimate }\end{array}$ & $\begin{array}{l}\text { R Square } \\
\text { change }\end{array}$ & F change & Df1 & Df2 & Sig.F change \\
\hline 1 & $.817^{\mathrm{a}}$ & .662 & .570 & $5.278 \mathrm{E} 9$ & .662 & 7.843 & 4 & 17 & .002 \\
\hline
\end{tabular}

Source: Researcher (2018)

Predictors: (Constant) STO, TF, FD, IT: b. Dependent: TAC

Note: Security Token Offerings-STOs; TaxFarming-TF; Fiscal Decentralisation-FD and Information Technology-IT

The model 3 summary shows that the R-adjusted measures the percentages of TAC that was explained by variations in the independent variables. Thus, the R-square adjusted shows that $57 \%$ variation in challenges of informal sector tax administration changes with change in STOs, IT, TF and FD. Tax farming and information and technology had a large beta, and this explains that these two variables make a contribution that is stronger in explaining TAC when variance controlled by other variables is maintained at a constant. STO made less contribution to explaining TAC. The regression model depicts that Information technology and tax farming made a unique stronger contribution to reducing the challenges in informal sector tax administration when the variance explained by other variables were held constant. A study by De Mel, McKenzie and Woodruff (2013) found out that the two variables (Information technology and tax farming) contribute to a reduction in the challenges in informal sector tax administration Ireland.

\subsubsection{Correlation Matrix}

A correlation matrix was done to test the relationship between the variables under consideration.

Table 14. Correlation matrix

\begin{tabular}{llllll}
\hline TAC & 1 & IT & TF & FD & STO \\
\hline IT & 0.6301 & 1 & & & \\
\hline TF & 0.6616 & 0.3207 & 1 & & \\
\hline FD & 0.8393 & 0.5517 & 0.5081 & 1 & 1
\end{tabular}

Source: Researcher (2018)

Note: Security Token Offerings-STOs; Tax Farming-TF; Fiscal Decentralisation-FD and Information Technology-IT 
In the study, the correlation coefficient for the variables information technology, tax farming, Fiscal Decentralisation was a positive and significant correlation between these variables and challenges in tax administration of the informal sector. Thus, the correlation matrix depicts that the independent variables correlate positively with TAC. However, the correlation matrix shows a merely negative relationship between TAC and STOs. This explains that STOs has minimum influence on the challenges of informal sector tax administration.

\subsubsection{Granger Causality}

Granger causality was done to test the probability and significance of the relationship between these four variables and their effect on Tax administration challenges.

Table 15. Granger causality

\begin{tabular}{lll}
\hline Null hypothesis & F-Static & Prob. \\
\hline TF does not granger cause TAC & 4.7978 & 0.014 \\
\hline TAC does not granger cause TF & 6.11062 & 0.0075 \\
\hline FD does not granger cause STO & 0.1409 & 0.778 \\
\hline STO does not granger cause IT & 4.9398 & 0.0231 \\
\hline \hline IT does not granger cause TAC & 0.7467 & 0.559 \\
\hline TAC does granger cause IT & 0.4532 & 0.7071 \\
\hline \hline TAC does not granger cause STO & 1.141 & 0.778 \\
\hline STO does not granger cause TAC & 4.9297 & 0.022 \\
\hline
\end{tabular}

Source: Researcher (2018)

Note: Security Token Offerings-STOs; Tax Farming-TF; Fiscal Decentralisation-FD and Information Technology-IT; Tax Administration Challenges-TAC.

From the Granger causality, the study does not reject the probability that challenges for tax administration does not granger cause STOs but rejects the hypotheses that STO does not granger cause reduction of challenges in informal sector tax administration. Thus, the granger causality runs from STO to Tax Administration Challenges (TAC) but not from TAC to STO. The study also rejects the hypothesis that Information Technology (IT) does not granger cause TAC but does not reject the hypothesis that IT granger cause TAC depicting that the granger cause runs from IT to TAC not vice-versa.

\section{Conclusions}

The study found out that although Presumptive tax collection has, to some extent, improved the revenue for the government, informal sector revenue as a percentage of total tax revenues has remained low, thus slow improvement. The study concluded that there is a great potential of revenue from the informal sector in Zimbabwe, as evidenced by the great share of GDP and the various roles played by the informal sector like employment creation. The study also noted that Zimra due to poor funding, over-reliance on manual systems and lack of qualified staff is not able to tax the informal sector effectively. This was emphasised by the over-reliance on simplistic presumptive taxes which many choose to ignore. This is partly due to poor administration of often poorly designed tax systems with resource constraints in the collection of revenue, causing widespread evasion. The study concluded that administrative agencies in the developing world and Zimbabwe in the particular face numerous challenges in mobilising tax revenue from the informal sector. The study also concludes that tax reforms such as tax farming and STOs have to some extend resulted in effective tax administration and somehow strengthened tax compliance by the informal sector. 


\section{Recommendations}

The research recommends that ZIMRA must set up small taxpayers" office for monitoring and evaluation of informal sector tax collections as this practice has brought success in some developing countries such as Zambia and Tanzania. Zimra can also beef up its staff and make sure they are well motivated. The research also recommended the adaptation of Information Communication Technology to ensure accountability and traceability of transactions in the informal sector as they move away from cash-based system recommendation. The researcher recommends that the informal sector should formalise their businesses which means the registration of the form of business with tax authorities and obtaining local authorities licenses so that they can enjoy many advantages like reduced corruption rates and harassment accessing funding as well as broadening of the tax base. However, such formalisation should be voluntary as some informal sector participants prefer to remain informal. The political will of the government to prosecute defaulters will be the most effective means of enforcing compliance. Legal prosecution is an enforcement measure which makes sure that defaulters shun tax evasion.

\section{References}

AFRODAD. (2014). What has Tax got to do with Development? A Critical look at Zimbabwe' Tax System. Africa Forum and Network on Debt and Development.

Alm, J., \& Torgler, B. (2011). Do ethics matter? Tax compliance and morality. Journal of Business Ethics, 101(4), 635-651. https://doi.org/10.1007/s10551-011-0761-9

Araujo-Bonjean, C., \& Chambas, G. (2005). Taxing the unrecorded urban economy in sub-Saharan Africa. In J. R. Alm, J. Martinez-Vazquez, \& S. Wallace (Eds.), Taxing the Hard-totax: Lessons from Theory and Practice (Vol. 268, pp. 313-329). Emerald Group Publishing Limited. https://doi.org/10.1016/S0573-8555(04)68815-8

Ariel, B. (2012). Deterrence and moral persuasion effects on corporate tax compliance: findings from a randomized controlled trial. Criminology an Interdisciplinary Journal, 50, 27-69. https://doi.org/10.1111/j.1745-9125.2011.00256.x

Ayee, J. (2007). Building tax compliance through reciprocity with government, Foreign Investment Advisory Service of the World Bank Group Regional Conference. Accra, Ghana.

Baruch, Y. (1999). Response rates in academic studies: a comparative analysis. Human Relations, 52, 421-434. https://doi.org/10.1177/001872679905200401

Baunsgaard, T. (2005). Tax revenue and (or?) trade liberalization. IMF papers, Washington DC.

Besley, T., \& Torsten, P. (2014). Why Do Developing Countries Tax So Little?. Journal of Economic Perspectives, 28(4), 99-120. https://doi.org/10.1257/jep.28.4.99

Bird, R. M. (2015). Improving tax administration in developing countries. Journal of Tax Administration, 1(1), 23-44.

Brou, D., \& Collins, K. (2001). A winning at Hiding and Seek: The Tax Mix and the Informal economy. Canadian Tax Journal/Revue FiscaleCanadienne, 49(6), 1539-1562.

Creswell, J. (2007). Qualitative inquiry and research design: choosing among five approaches (2nd ed.). California: Thousand Oaks.

Dalu, T., Maposa, V. G., Dalu, T., \& Pabwaungana, S. (2013). Awareness and compliance levels of informal traders with regards to their presumptive tax obligations: A case of Harare Central Business District informal traders. African Journal of Economic and Sustainable Development, 2(4), 297-308. https://doi.org/10.1504/AJESD.2013.058745

De Mel, S., McKenzie, D., \& Woodruff, C. (2013). The demand for, and consequences of, formalization among informal firms in Sri Lanka. American Economic Journal: Applied Economics, 5(2), 122-150. https://doi.org/10.1257/app.5.2.122

Dube, G. (2014). Informal sector Tax Administration in Zimbabwe. Public Administration and Development, 34(48), 42-62. https://doi.org/10.1002/pad.1673

Feige, E. L. (2016). Reflections on the Meaning and Measurement of Unobserved Economies: What do we know about the "Shadow Economy?". Journal of Tax Administration, 2(1), 5-41. https://doi.org/10.2139/ssrn.2705879

Fleming, M. H., Roman, J., \& Farrell, G. (2000). The Shadow Economy. Journal of International Affairs, 53(2), Spring, 387-409. 
Frey, B., \& Torgler, B. (2007). Tax morale and conditional cooperation. Journal of Comparative Economics, 35(1), 136-159. https://doi.org/10.1016/j.jce.2006.10.006

Glenday, G. (2006). Toward fiscally feasible and efficient trade liberalization. Durham, NC: Duke Center for Internal Development, Duke University. Retrieved from http://www.fiscalreform.net/library/pdfs/Glenday_paper_May_18,_2006_SA_\%20rev.pdf

Gupta, S., \& Tareq, S. (2008). Mobilizing revenue. Finance and Development, 45(3), 44-47.

Gurtoo, A., \& Williams, C. (2009). Entrepreneurship and the informal sector: Some lessons from India. Entrepreneurship and Innovation, 10(1), 1-8. https://doi.org/10.5367/000000009787414280

Joseph, E. (2015). Taxing the Informal Economy in Nigeria: Issues, Challenges and Opportunities. International Journal of Business and Social Science, 6(10), 160-175.

Joshi, A., Prichard, W., \& Heady, C. (2014). Taxing the informal economy: The current state of knowledge and agendas for future research. Journal of Development Studies, 50(10), 1325-1347. https://doi.org/10.1080/00220388.2014.940910

Katairo, I. R. (2011). Level of revenue collection and service delivery in local government. Kampala, Uganda: Makerere University.

Kenyon, T. (2007). A framework for thinking about enterprise formalization policies in developing countries. World Bank Policy Research Working Paper 4235, Washington DC; World Bank. https://doi.org/10.1596/1813-9450-4235

Levi, M. (1998). The State of Trust. In V. Braithwaite, \& M. Levi (Eds.), Trust and governance. New York: Russell Sage Foundation.

Masarirambi, C. (2013). An investigation into factors associated with tax evasion in the Zimbabwe informal sector: A survey of MagabaMbare informal traders. PhD thesis, Zimbabwe Open University, Harare.

Mascagni, G., Moore, M., \& McCluskey, R. (2014). Tax revenue mobilisation in developing countries: issues and challenges (pp. 1-36). European Parliament - Directorate-General for External Policies of the Union.

Mbaye, A. A., \& Benjamin, N. (2014). Informality, Growth and development in Africa. The Oxford Handbook of Africa and Economics, 1. https://doi.org/10.1093/oxfordhb/9780199687114.013.11

Memon, N. (2013). Looking at Pakistani presumptive income tax through principles of a good tax?. Journal of Tax Research, 11(1), 40-78.

Munjeyi, E. (2017). Informal sector taxation: Is there anything worth more Researching!. Research Journal of Finance and Accounting, 20(8).

Munjeyi. (2018). The informal sector in Africa an invisible force with visible impact evidence from Botswana and zimbabwe. International Journal of Innovative Research in Science, Engineering and Technology, 7(8), 8616-8625.

Munyoro, G., Chikombingo, M., \& Nyandoro, Z. (2016). The motives of Zimbabwean entrepreneurs: a case study of harare. Africa Development and Resources Research Institute Journal, 25(7), 1-13.

Mwanza, L. (2015). Africa portal. Retrieved from https://www.africaportal.org

Mwila, A., Manley, D., Chileshe, P., Phiri, E., \& Mpembamoto, K. (2011). The taxation system in Zambia, Jesuit Centre for Theological Reflection, Lusaka.

Otekunrin, A. O., Asamu, F. F., Oye, O. O., \& Olowookere, J. K. (2019). Current market price of share capital and profitability of selected on Nigerian stock exchange. International Journal of Civil Engineering and Technology, 10(1), 1274-1287.

Otekunrin, A. O., Fagboro, D. G., Nwanji, T. I., Asamu, F. F., Ajiboye, O. B., \& Falaye, J. A. (2019). Performance of deposit money banks and liquidity management in Nigeria. Banks and Bank Systems, 14(3), 152-161. https://doi.org/10.21511/bbs.14(3).2019.13

Otekunrin, A. O., Iyoha, F. O., Uwuigbe, U., \& Uwuigbe, O. R. (2017). Adoption of International Financial Reporting Standard, capital structure and profitability of selected quoted firms in Nigeria. Proceedings of the 29th International Business Information Management Association Conference - Education Excellence and 
Innovation Management through Vision 2020: From Regional Development Sustainability to Global Economic Growth (pp. 3788-3796).

Otekunrin, A. O., Nwanji, T. I., \& Obasaju, B. O. (2018). Capital structure and profitability of selected agriculture and agro-allied firms on Nigerian stock exchange: Post international financial reporting standard analysis. International Journal of Civil Engineering and Technology, 9(12), 1615-1625.

Otekunrin, A. O., Nwanji, T. I., Agba, D. Z., Olowookere, J. K., Fakile, S. A., Lawal, S. A., .. Falaye, A. J. (2018). Effect of Taxation on Corporate Investment: A case study of Cadbury, Nestle and Federal Inland Revenue Service. Proceedings of the 32nd International Business Information Management Association Conference (pp. 7483-7398).

Otekunrin, A. O., Nwanji, T. I., Egbide, B., Fakile, S. A., Lawal, A. I., Ajayi, S. A., ... Eluyela, D. F. (2018). Financial Ratio Analysis and Market Price of Share of Selected Quoted Agriculture and Agro-allied firms in Nigeria after Adoption of International Financial Reporting Standard. The Journal of Social Sciences Research, 4(12), 736-744.

Pimhidzai, O., \& Fox, L. (2012). Taking from the poor or local economic development: The dilemma of taxation of small informal enterprises in Uganda. World Bank, Washington DC.

Sakuhuni. (2014). Causes, benefits and costs of informal economy: evidence from Zimbabwe (1980-2013). Research Journal of Commerce, 2(4).

Saunders, L., \& Thornhill. (2009). Research methods for business students fourth edition. London: Prentice Hall.

Scandura, T. A., \& Williams, E. (2013). Research methodology in management: current practices, trends, and implications for future research. Academy of Management Journal, 43(6). https://doi.org/10.2307/1556348

Schneider, F., \& Buehn, A. (2009). Shadow economies and corruption all over the world: revised estimates for 120 countries. Economics: The Open-Access, Open-Assessment E-Journal, 1(2).

Sikwila, M. N., Kareza, G., \& Mungadza, A. (2016). Tax collection constraints and tax burden on the urban informal sector Enterprises: evidence from Bulawayo Zimbabwe. Mediterranean Journal of Social Sciences, 7(6), 79. https://doi.org/10.5901/mjss.2016.v7n6p79

Uganda Revenue Authority. (2011). Taxation Handbook: A guide to Taxation in Uganda. Kampala: Fountain Publishers.

Utaumire, B., Mashiri, E., \& Mazhindu, K. (2013). Effectiveness of presumptive tax system in Zimbabwe: case of ZIMRA region one. Research Journal of Finance and Accounting, 4(7), 114-121.

Wellalage, N. H., \& Locke, S. (2016). Informality and creditconstraints: evidence from Sub-Saharan African MSEs. Applied Economics, 48(29), 2756-2770.https://doi.org/10.1080/00036846.2015.1128081

Williams, C., \& Schneider, F. (2013). The shadow economy, the Institute of Economic Affairs. London.

ZIMRA. (2019). Zimrawebsite. Retrieved from https://www.zimra.co.zw/

Zivanai, O., Onias, M., Nhamo, H., Lloyd, C., \& Michael, M. (2014). The effectiveness of Presumptive tax and its impact on the profitability of SMEs in Zimbabwe: Case of Commuter Transport operators in Zimbabwe. Researchjournali's Journal of Commerce, 2(7), 1-22.

\section{Copyrights}

Copyright for this article is retained by the author(s), with first publication rights granted to the journal.

This is an open-access article distributed under the terms and conditions of the Creative Commons Attribution license (http://creativecommons.org/licenses/by/4.0/). 